\section{ANALYSIS OF WEBSITES \\ BELONGING TO PUBLIC UNIVERSI- TIES FROM THE PERSPECTIVE OF THE DEMOCRATIC GOVERNANCE EXIGENCIES. A MARKETING RESEARCH APPROACH}

\section{Corina RĂDULESCU \\ Oana Simona (Caraman) HUDEA}

Răzvan Mihail PAPUC

\section{Corina RĂDULESCU}

Associate Professor, Department of Economic and Administrative Sciences, Faculty of Administration and Business,

University of Bucharest, Romania

Tel: 0040-740-180.067

E-mail: corina.radulescu@faa.unibuc.ro

Oana Simona (Caraman) HUDEA

Associate Professor, Department of Economic and Administrative Sciences, Faculty of Administration and Business,

University of Bucharest, Romania

Tel: 0040-726-322.955

E-mail: oana.hudea@faa.unibuc.ro

\section{Răzvan Mihail PAPUC}

Associate Professor, Department of Economic and Administrative Sciences, Faculty of Administration and Business,

University of Bucharest, Romania

Tel: 0040-740-052.752

E-mail: razvanmihail.papuc@faa.unibuc.ro

\section{Abstract}

The Democratic Governance Model generates a visible opening of institutions towards citizens. By analyzing ten digital communication offers made by Romanian state universities, we pursue to observe if any partnership relationship with their users is created, if their websites are conceived so as to facilitate the participation of students in the activity of the institution, to comply with the manifested needs and to invite to dialogue. The result of the research reveals different degrees of fidelity of the studied websites to the new management model.

Keywords: public communication, Democratic Governance, university website, e-Participation, online services, quick access to information, site attractiveness. 


\section{Introduction}

Given that Internet provides real opportunities for achieving the Democratic Governance principles, we undertake to analyze the digital communication offers of ten Romanian state universities and to assess if they comply with the requirements of the new management model, if they have passed from an institutional logic to a logic of services, favoring the involvement of users (e-Participation). The final classification of websites reveals the level of openness of each institution: if there is a partnership-type collaboration with students, if a dialogue with the latter is put in place, if the user logic is observed - the posted information is useful and updated and it is quickly accessible.

As result of the data analysis, performed by resorting to the partial use of the adapted Semantic Differential Scale and to the implementation of the Fishbein-Rosenberg Model, we obtained a top of the websites belonging to the ten universities considered, studied from the perspective of the following criteria: the student involvement level - the use of social networks: Facebook, Twitter (sntw_inv), the existence of online instruments able to reveal and allow for the consideration of the opinion of students: questionnaires, services for suggestions, barometers (need_conf), the user quick access to information (qck_access), mainly rendered by the rule of 3 clicks in accessing some important services (e-Learning platform, tuition fee page, public acquisition service page) and by the existence of a helpful website map able to accelerate such access, the website user-friendly and attractive feature (web_style), captured based on the existence of visual identity manuals, on the font adjustment-related possibilities and on the integration and complexity of multimedia elements (university virtual tour, moving images, presentation spot, photo gallery, hymn, brochure, radio, television and so on). The result of our research suggests different degrees of adaptation of the studied websites to the Democratic Governance Model.

The structure of the paper follows a smooth path from the theoretical background towards the empirical analysis, revealing, after a brief introduction, in the current section, the overall context of the studied issues, in section 2, the methodology used in achieving the final results, in section 3 , with the main findings and the interpretation thereof, in section 4 , and the related recommendations, in section 5 . The paper ends with conclusions, a brief rendering of the entire scientific effort, in section 6 .

\section{Setting the context}

\subsection{Increasing the autonomy and 'openness' of the public institution to the citizen along with the Democratic Governance model}

The bureaucratic model based on the pre-eminence of law (Chevallier, 2012, p. 27) involves a legal domination (a fair form of organization of the administration that excludes the inequality of treatment), unwittingly increasing the distance between organization and citizens (turned into simple administered entities). In this reference model of the administration conduct, the principle of publicity - so much supported by the open democratic system - is limited to the publishing of laws, of the legal decisions and to the transparency of the public debates (in Parliament and in justice). 
Various movements changed this attitude - the New Public Management (based on the efficiency of public actions and on the predominant commercial orientation of the public service), then, at the beginning of this millennium, the Democratic Governance emerged. The public institutions began to gradually open to citizens - the latter becoming customers and partners. The administration cannot be perceived as a closed entity, but rather as an organization opened to public, collaborating in a partnership manner with all other actors (Pasquier, 2011, p. 27; Mégard, 2012, p. 23; Lemaire and Zémor, 2006, p. 83).

The electronic media, especially Internet, provide real opportunities for observing the exigencies of the administration new management models: The New Public Management (culture of results) and the Democratic Governance. The New Public Management increases the public institution's autonomy (Osborne, 2010, p. 79) and intensifies the institutional and commercial communication, making visible the institutional activity and achieving the satisfaction of users. The communication activities multiply: organization of events, publishing of activity reports, increased media presence, development of internal structures responsible for such activities, etc. Organizations develop their own websites and visual identities (e.g., logo) in order to confer their actions a precise visibility, to position themselves on the market (to compete with other public organizations) and, not least, to provide commercial services. The New Public Management focuses on the consideration of the needs and expectations of citizens (become customers) whenever an institution conceives and delivers public services.

This opening towards citizens of the organization is even more visible within the Democratic Governance model (Bevir, 2009, p. 49; Lacroix and St-Arnaud, 2012, p. 20). This new model creates a partnership relationship with citizens, broadly informing them so as to get their involvement and participation in the conceiving of the administrative action (Marga, 2010). Communication is highly developed, as it is normal for a participating and responsible organization, and the distance between institution and citizens is reduced - opportunity especially provided by Internet.

The Democratic Governance is structured around the principles of accountability and transparency, networking governance and co-production of public policies, the implications on the public communication being essential. The institution should work in partnership with its publics - to provide information, to animate workshops, to invite media for discussions and, above all, to publicly justify its activities.

The publicity principle (the obligation to provide any available information to media and to population) is more alive than ever, and citizens become co-creators of the administrative action.

\subsection{Electronic communication provides real opportunities for achieving the exigen- cies of the Democratic Governance Model}

The logic of new governance models, valuating the participation, the dialogue between institution and citizens and the transparency of information - electronic communication (Internet, social networks), provides real opportunities, among which the 
following can be mentioned:

- the interactive facet of the communication tool (the transmitter - receiver relationship ceases to be frozen because the roles can continuously interchange, as in an interpersonal relationship);

- we place ourselves more and more in a network logic, where institutions and individuals exchange information observing a hierarchy that evolves based on other factors than the institutional authority (Anderruthy, 2009, p. 39; Cousin, 2008, p. 27);

- via Internet, institutions have the possibility to increase the transparency of their services and activities, to publicly justify them (for example, the online answer to the questions addressed by people), to facilitate the participation of citizens in public policies and to increasingly involve them in the governance system (Monnoyer-Smith, 2011, p. 158);

- by individualizing the relationship with specific applications, like my-public-service, the public institutions are able to better comply with the needs of individuals and to increase the public service efficiency (virtual counter $24 / 24 \mathrm{H}$, almost zero waiting time);

- the multimedia possibilities provided by Internet help institutions in adapting themselves and in reaching more people in an attractive and friendly manner (Nielsen and Loranger, 2009; Blond et al., 2009);

- the advantage of allowing for an asynchronous communication, knowing that interlocutors are not necessarily simultaneously connected to the system (Gany, 2009; Bădău, 2011);

- the up to date feature of information - if this is published / read during the same day - allows institutions to communicate in real time and beneficiaries to always benefit from updated information, therefore reducing the distance between institutions and citizens;

- the simultaneous accomplishment of several functions of the public communication;

- the reduction of the communication costs as an Internet advantage (Ridgway, 2001), etc.

Adequately used, this communication tool simultaneously contributes to the principles of the New Public Management and to those of the Democratic Governance.

In essence, our application focuses on highlighting the extent to which the websites of the ten state universities analyzed encourage user involvement, invite students to dialogue (a pillar of Democratic Governance) and meet its logic.

\section{Methodology}

The empirical analysis is centered on the identification of the level of involvement and utility provided to their students by the websites of ten representative state Romanian universities, namely: University of Bucharest (ub), Babes-Bolyai University (ubb), West University of Timisoara (uvt), Alexandru Ioan Cuza University of Iasi 
(uaic), Bucharest Academy of Economic Studies (ase), Lucian Blaga University of Sibiu (ulb), Transylvania University of Brasov (utb), University of Craiova (ucv), Ovidius University of Constanta (uov) and Stefan cel Mare University of Suceava (usv).

To this end, several prerequisites had to be successively complied with: determination of the evaluation criteria, establishment of the criteria-based evaluation procedures, effective appreciation of the studied entities through the eye of each and every criterion and final classification of the same in accordance with the arising aggregated criteria scores.

\subsection{Evaluation criteria}

The first step was represented by the selection of four evaluation criteria, deemed by us to be essential in revealing the degree of involvement (satisfaction) generated to the target users when dealing with such websites:

- the user social network involvement criterion (sntw_inv), reflected by the existence and use of the website integrated social networks: Facebook (likes, visits), Twitter (tweets, following, followers, favorites, lists) and others assimilated;

- the user need conformity criterion (need_conf), outlined by the existence of online instruments able to reveal and allow for the consideration of the opinion of students (questionnaires, services for suggestions and claims, satisfaction barometers and others);

- the user quick access to information criterion (qck_access), mainly revealed by the rule of 3 clicks in accessing some important services (e-Learning platform, tuition fee page, public acquisition service page) and by the existence of a helpful website map able to accelerate such access;

- the website user-friendly and attractive feature criterion (web_style), captured based on the existence of visual identity manuals, on the font adjustment-related possibilities and on the integration and complexity of multimedia elements (university virtual tour, moving images, presentation spot, photo gallery, hymn, brochure, radio, television and so on).

\subsection{Criteria-based evaluation procedures}

Considering the marketing research specific approach, we decided to resort to the gradual use of two specific measurement scales: a partial adjusted version of the Semantic Differential Scale and the Fishbein-Rosenberg Model.

\subsubsection{Semantic Differential Scale}

First of all, the performance of the studied entities has been subject to a criteria-based quantification via a scale, abutted, on extremities, upon bipolar appreciation attributes, this issue making us relate our information analysis to the Semantic Differential instrument.

However, the significant adjustment of the above-mentioned scale came from its translation into a pattern characterized by an increased number of levels inserted be- 
tween the said poles, resulting in a total of 11 items, ranging from 0 (extremely bad) to 10 (extremely good), instead of a maximum of 7 , revealed by the literature in the matter.

The idea of such an extension emerged from the decision of subsequently transposing this scale into the framework of the Fishbein-Rosenberg Model, in order to get a more grounded analysis of the studied items, model requiring a 0 to 10 , assimilable to 0 to 1 , range.

In fact, only the initial evaluation grades arising from the adjusted Semantic Differential analysis were used, the later transformations being exclusively made in compliance with the second type of scale, namely the Fishbein-Rosenberg Model.

\subsubsection{Fishbein-Rosenberg Model}

Once the grades assigned, by taking into account, in this respect, the two opposite poles of the Semantic Differential, we focused on the additional elements required in order to apply the Fishbein-Rosenberg Model.

This involved, beside the already discussed evaluation, the assessment, also from 0 to 10 , of the used criteria themselves, without considering the analyzed entities, therefore helping in revealing the degree of incidence of every single such criterion upon the overall image of the websites belonging to the higher education public institutions had in view.

After having divided by 10 the grades assigned to each entity for each of the four related criteria, and after having normalized the criteria themselves, so as to turn the 0 to 10 range into the 0 to 1 range, as specified above, we computed, for the former, the arithmetic mean weighted with the values representing the relative appreciation of the investigated criteria, according to the formula:

$$
F G_{j}=\sum_{i=1}^{n}\left(P G_{i j} \times C G_{i}\right)
$$

with $F G_{j}$ representing the 10 divided final grades assigned to the website of the higher education unit $j, P G_{i i^{\prime}}$ the 10 divided partial grades assigned to the website of the higher education unit $j$ based on each $i$ of the total of $n$ criteria considered, and $C G_{i^{\prime}}$ the normalized grade assigned to each criterion $i$, this operation allowing for getting the final, aggregated grade and, as a consequence, the classification of the related units.

It is important to mention that the choice of both the evaluation criteria and the criteria-based evaluation procedures in this context of analysis is an original one as, although independently applied in the literature, in different frameworks, the same have not been used altogether in order to reveal the compliance with the Democratic Governance Exigences (given our related information in the matter, based on the studied literature).

Thus, the evaluation criteria used, commonly encountered and accepted when dealing with the new management model (Osborne, 2010; Pasquier, 2011), are ap- 
plied herein in the particular case of the online communication of specific public institutions with their target audience, with the purpose of identifying the main weaknesses encountered in such respect.

On the other hand, the criteria-based evaluation procedures, non-parametric techniques useful in analyzing qualitative data or quantitative data lacking the main arguments in order to be adequate for a parametric analysis, besides their use herein also in a particular context, have been partly adjusted so as to work altogether, a combination of these two procedures - Semantic Differential Scale and Fishbein-Rosenberg Model - as such, being a novelty in the matter. Such adjustment, rendered and explained into larger detail above, emerged from the trial to cover the problems revealed by the statements as to the limitations of the Fishbein-Rosenberg Model, initially made many years ago (Laroche, 1978, p. 175), and resumed, subsequently, by different other authors, relating to the scaling decision issue (origin and range) and to the one of the relationship among attributes (interaction and halo effects). By using disparate well-known instruments in a highly customized way, while trying to keep to a minimum level the subjective appreciation (impossible to eliminate in full in a partly qualitative approach), we consider to have succeeded in laying the grounds for an impartial and correct analysis of facts.

\section{Empirical analysis results}

The main findings of the empirical analysis, ending in the rendering of the final classification of ten Romanian state universities, given their digital communication offers, are dedicated to the observance of the existence of any partnership relationship of the said entities with their users, of their effort in conceiving websites facilitating the participation of students in the activity of the institution, of their compliance with the manifested needs of the target public and of their availability for inviting the same to dialogue. As rendered below, the results of the research reveal different levels of fidelity of the studied websites to the new management model, therefore bringing useful information as to the encountered gaps that should be covered by each related institution in order to improve its performance in the matter.

\subsection{Criteria-based evaluation results}

By using the already described criteria in analyzing the utility of the websites belonging to the above-mentioned target public universities and by resorting to the Semantic Differential Scale in assigning a grade for each unit by virtue of every independent characteristic, we got the results rendered hereinafter in Tables 1, 2, 3 and 4 and graphically transposed, by means of Excel 2003, into Figures 1, 2, 3 and 4. 
Table 1: Results obtained based on the user social network involvement criterion

\begin{tabular}{|c|c|c|c|}
\hline \multirow[t]{2}{*}{ Higher Education Public Institution } & \multicolumn{2}{|c|}{$\begin{array}{l}\text { User social network involvement } \\
\text { criterion }\end{array}$} & \multirow[t]{2}{*}{ Grade } \\
\hline & Facebook & Twitter & \\
\hline University of Bucharest & $\begin{array}{l}65,017 \text { likes } \\
43,594 \text { visits }\end{array}$ & $\begin{array}{c}4,255 \text { tweets } \\
178 \text { following } \\
1,174 \text { followers } \\
187 \text { favorites }\end{array}$ & 10 \\
\hline Babes-Bolyai University & $\begin{array}{c}23,340 \text { likes } \\
730 \text { visits }\end{array}$ & $\begin{array}{c}\text { 1,166 tweets } \\
4 \text { following } \\
485 \text { followers }\end{array}$ & 6 \\
\hline West University of Timisoara & $\begin{array}{l}21,850 \text { likes } \\
66,359 \text { visits }\end{array}$ & $\begin{array}{c}1,153 \text { tweets } \\
7 \text { following } \\
705 \text { followers }\end{array}$ & 9 \\
\hline Alexandru loan Cuza University of lasi & $\begin{array}{l}60,422 \text { likes } \\
28,826 \text { visits }\end{array}$ & $\begin{array}{c}2,630 \text { tweets } \\
42 \text { following } \\
1267 \text { followers } \\
5 \text { favorites }\end{array}$ & 9 \\
\hline Bucharest Academy of Economic Studies & $\begin{array}{l}10,552 \text { likes } \\
22,633 \text { visits }\end{array}$ & $\begin{array}{l}107 \text { tweets } \\
374 \text { followers }\end{array}$ & 7 \\
\hline Lucian Blaga University of Sibiu & $\begin{array}{l}16,284 \text { likes } \\
17,410 \text { visits }\end{array}$ & $\begin{array}{c}444 \text { tweets } \\
4 \text { following } \\
710 \text { followers } \\
4 \text { lists }\end{array}$ & 7 \\
\hline Transylvania University of Brasov & $\begin{array}{c}16,672 \text { likes } \\
601 \text { visits }\end{array}$ & - & 4 \\
\hline University of Craiova & 10,319 likes & - & 3 \\
\hline Ovidius University of Constanta & - & - & 1 \\
\hline Stefan cel Mare University of Suceava & $\begin{array}{l}21,150 \text { likes } \\
1 \text { visit }\end{array}$ & $\begin{array}{c}1,962 \text { tweets } \\
54 \text { following } \\
431 \text { followers } \\
1 \text { list }\end{array}$ & 5 \\
\hline
\end{tabular}

This corresponds to the graphical representation in Figure 1.

As revealed by both Table 1 and Figure 1, the best positioned universities from the perspective of the user social network involvement criterion reflected by their websites are: University of Bucharest, West University of Timisoara and Alexandru Ioan Cuza University of Iasi, while the worst positioned ones are: University of Craiova and Ovidius University of Constanta.

This might suggest the tremendous importance of social networks in the communication process, especially when dealing with youth, has not been perceived as such by some of the analyzed institutions, these ones either refusing in making them available on their websites or rendering them less visible to the target audience, therefore diminishing the chances of an active reaction of the latter in this regard. 


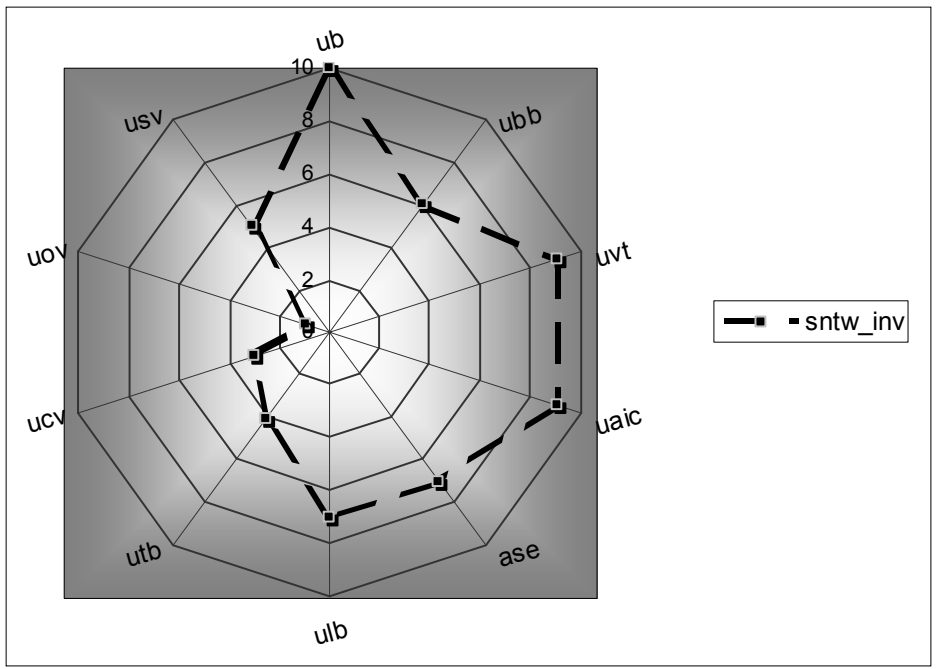

Figure 1: Results obtained based on the user social network involvement criterion

Table 2: Results obtained based on the user need conformity criterion

\begin{tabular}{lcccc}
\hline \multirow{2}{*}{ Higher Education Public Institution } & \multicolumn{3}{c}{ User need conformity criterion } \\
\cline { 2 - 4 } & Questionnaires & $\begin{array}{c}\text { Services for suggestions } \\
\text { and claims }\end{array}$ & $\begin{array}{c}\text { Satisfaction } \\
\text { barometers }\end{array}$ & Grade \\
\hline University of Bucharest & no & yes & no & $\mathbf{8}$ \\
Babes-Bolyai University & yes & no & yes & 10 \\
West University of Timisoara & no & yes & yes & 10 \\
Alexandru loan Cuza University of lasi & no & no & yes & 7 \\
Bucharest Academy of Economic Studies & yes & no & no & $\mathbf{8}$ \\
Lucian Blaga University of Sibiu & yes & no & yes & 10 \\
Transylvania University of Brasov & no & yes & yes & $\mathbf{9}$ \\
University of Craiova & no & no & no & $\mathbf{2}$ \\
Ovidius University of Constanta & no & no & no & $\mathbf{2}$ \\
Stefan cel Mare University of Suceava & no & yes & no & $\mathbf{8}$ \\
\hline
\end{tabular}

Figure 2, illustrating the data contained in Table 2, takes the following form:

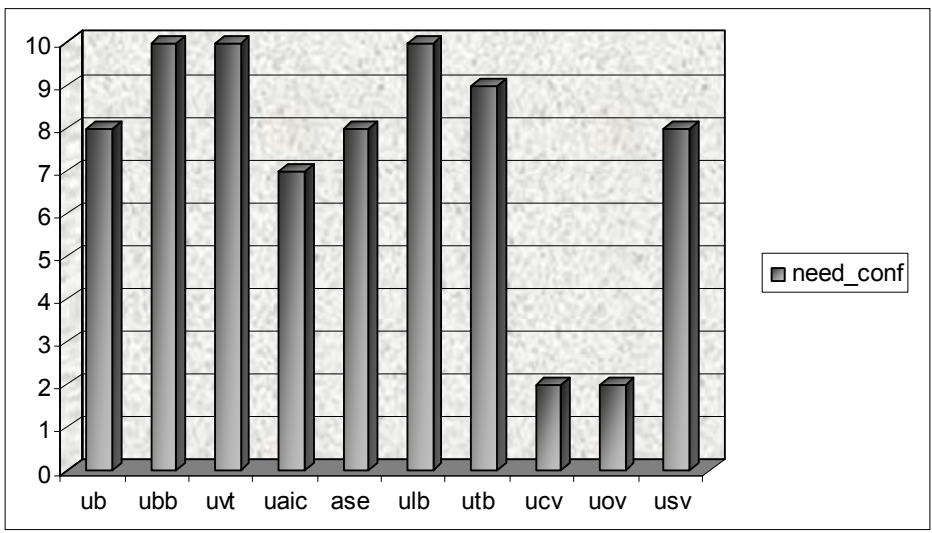

Figure 2: Results obtained based on the user need conformity criterion 
The representative bars in Figure 2 clearly delimitate, by resorting to the user need conformity criterion, the most adequate websites, belonging to Babes-Bolyai University, West University of Timisoara and Lucian Blaga University of Sibiu, from the less adequate ones, those of University of Craiova and Ovidius University of Constanta.

Although the majority of the analyzed institutions had in view at least one instrument useful in analyzing the opinions of the consumers of educational services, we encounter universities skipping on this important issue, perhaps being rather focused on the classical methods of expression of viewpoints, such as written claims or suggestions, without being aware of the significant limitations thereof, both in terms of reaction of the public audience and in terms of timely response of the entitled entities.

Table 3: Results obtained based on the user quick access to information criterion

\begin{tabular}{lccccc}
\hline \multirow{3}{*}{ Higher Education Public Institution } & \multicolumn{3}{c}{ User quick access to information criterion } & \\
\cline { 2 - 5 } & \multicolumn{2}{c}{ The rule of 3 clicks to destination } & Website & Grade \\
\cline { 2 - 5 } & $\begin{array}{c}\text { E-Learning } \\
\text { platform }\end{array}$ & $\begin{array}{c}\text { Tuition fee } \\
\text { page }\end{array}$ & $\begin{array}{c}\text { Acquisition } \\
\text { service page }\end{array}$ & map & \\
\hline University of Bucharest & no & yes & yes & yes & 7 \\
Babes-Bolyai University & yes & yes & yes & yes & 10 \\
West University of Timisoara & yes & yes & yes & no & 9 \\
Alexandru loan Cuza University of lasi & yes & yes & yes & yes & 10 \\
Bucharest Academy of Economic Studies & yes & yes & yes & yes & 10 \\
Lucian Blaga University of Sibiu & yes & yes & yes & yes & 10 \\
Transylvania University of Brasov & yes & yes & yes & no & 8 \\
University of Craiova & yes & yes & yes & yes & 10 \\
Ovidius University of Constanta & yes & no & no & no & $\mathbf{5}$ \\
Stefan cel Mare University of Suceava & yes & yes & yes & yes & 10 \\
\hline
\end{tabular}

The projection of Table 3 into a graphical pattern is captured in Figure 3. This one shows an obvious positioning of most of the analyzed universities in the upper part of the scale, given the user quick access to information criterion applied to their specific websites, the top position being held by six such institutions: Babes-Bolyai University, Alexandru Ioan Cuza University of Iasi, Bucharest Academy of Economic Studies, Lucian Blaga University of Sibiu, University of Craiova and Stefan cel Mare University of Suceava, while the last one by Ovidius University of Constanta.

Clearly, the analyzed public institutions should understand how important it is to consider the $6^{\text {th }} \mathrm{P}$ element of the marketing mix - processes. Idle times or lack of easy access to a service of any kind might cause dissatisfaction to customers. Fortunately, save for a singular case, the access to different services is usually provided by the related institutions but, in order to improve their relationship with the target audience, they should continuously work on increasing the performance in the matter. 


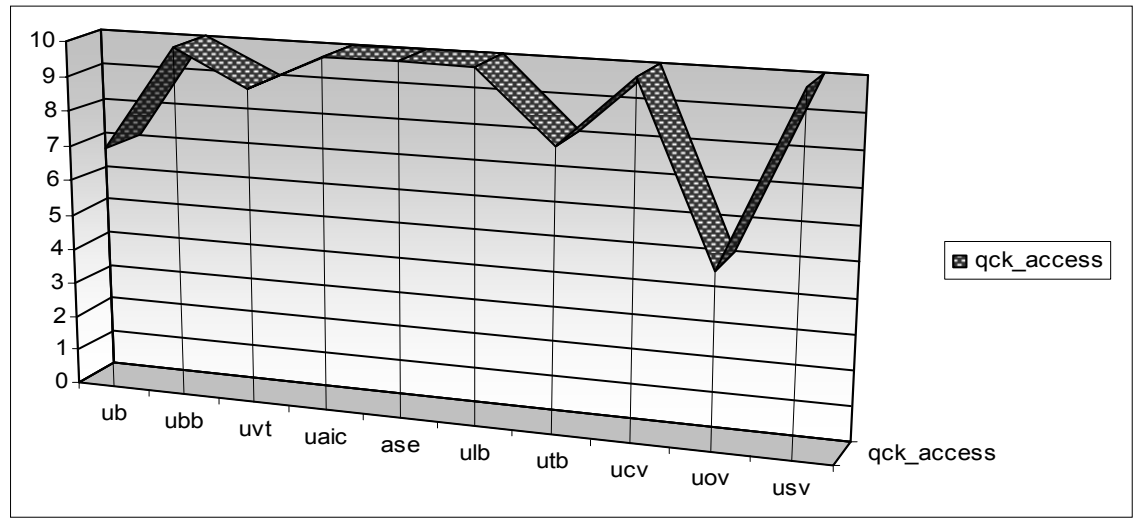

Figure 3: Results obtained based on the user quick access to information criterion

Table 4: Results obtained based on the website user-friendly and attractive feature criterion

\begin{tabular}{|c|c|c|c|c|}
\hline \multirow[b]{2}{*}{ Higher Education Public Institution } & \multicolumn{3}{|c|}{ Website user-friendly and attractive feature criterion } & \multirow[b]{2}{*}{ Grade } \\
\hline & $\begin{array}{l}\text { Visual identity } \\
\text { manuals }\end{array}$ & $\begin{array}{l}\text { Font-adjustment-related } \\
\text { possibilities }\end{array}$ & $\begin{array}{l}\text { Multimedia } \\
\text { elements }\end{array}$ & \\
\hline University of Bucharest & no & no & photos & 7 \\
\hline Babes-Bolyai University & yes & no & $\begin{array}{l}\text { virtual tour } \\
\text { photo gallery } \\
\text { brochure } \\
\text { radio }\end{array}$ & 9 \\
\hline West University of Timisoara & yes & yes & $\begin{array}{c}\text { virtual tour } \\
\text { moving images } \\
\text { photo gallery } \\
\text { hymn } \\
\text { brochure }\end{array}$ & 10 \\
\hline $\begin{array}{l}\text { Alexandru loan Cuza University of } \\
\text { lasi }\end{array}$ & yes & no & $\begin{array}{l}\text { virtual tour } \\
\text { moving images } \\
\text { photo gallery }\end{array}$ & 9 \\
\hline $\begin{array}{l}\text { Bucharest Academy of Economic } \\
\text { Studies }\end{array}$ & yes & no & $\begin{array}{c}\text { virtual tour } \\
\text { moving images } \\
\text { TV }\end{array}$ & 9 \\
\hline Lucian Blaga University of Sibiu & yes & no & $\begin{array}{l}\text { moving images, } \\
\text { presentation spot } \\
\text { brochure }\end{array}$ & 8 \\
\hline Transylvania University of Brasov & no & no & $\begin{array}{l}\text { moving images, } \\
\text { presentation spot }\end{array}$ & 7 \\
\hline University of Craiova & no & no & $\begin{array}{l}\text { virtual tour } \\
\text { moving images } \\
\text { photo gallery } \\
\text { presentation spot }\end{array}$ & 8 \\
\hline Ovidius University of Constanta & no & no & photo gallery & 6 \\
\hline $\begin{array}{l}\text { Stefan cel Mare University } \\
\text { of Suceava }\end{array}$ & no & no & $\begin{array}{l}\text { 3D virtual tour } \\
\text { moving images } \\
\text { photo gallery } \\
\text { hymn } \\
\text { radio }\end{array}$ & 9 \\
\hline
\end{tabular}


A more homogenous case is encountered in Table 4, rendered by Figure 4 below:

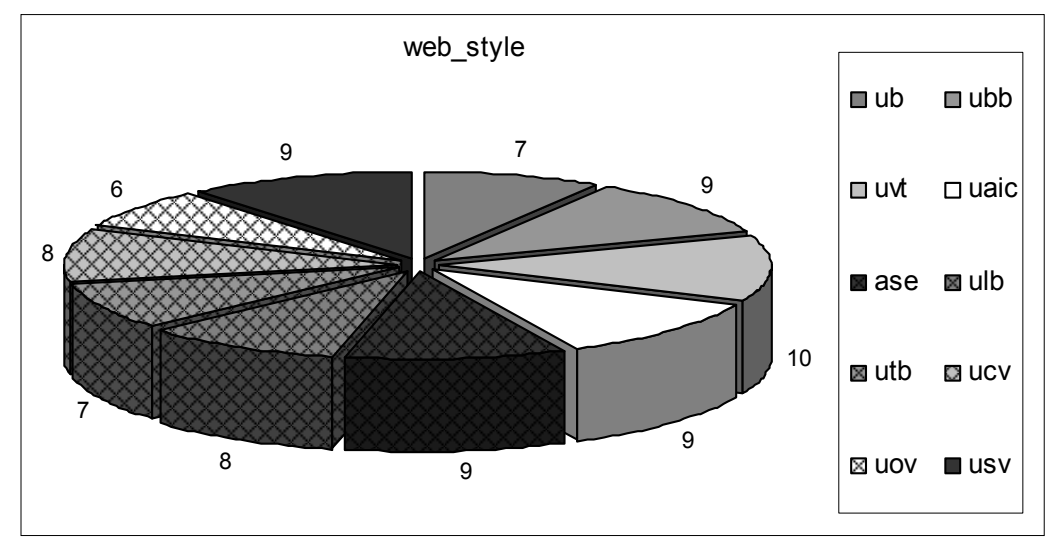

Figure 4: Results obtained based on the website user-friendly and attractive feature criterion

The specific representation of Table 4 via Figure 4 does not reveal a visible differentiation between the websites analyzed by considering the website user-friendly and attractive feature criterion, the transition from one position to another being smooth. In this case, the first position goes to West University of Timisoara and the last one to Ovidius University of Constanta.

It is well-known that most individuals, and especially youth, are attracted rather by visual and aural elements like images, movies, songs and so on than by texts, the former having a higher impact on them and, sometimes, being imprinted in their memory for longer time horizons. This is the reason why all institutions should try to adapt their strategy in order to establish a stronger communication with the same at this level.

It should be mentioned that, for Tables 2, 3 and 4, the final grade was assigned considering also other issues difficult to render in a yes/no assertion, like the complexity of an existing item, the qualitative difference between the same elements of the studied units, the existence of some additional, less important items, not rendered in these tables, but still deserving to be considered in capturing the level of accomplishment of a given criterion and so on.

\subsection{Computation of aggregated scores and final classification}

The first step in determining, by means of the Fishbein-Rosenberg Model, the overall value of the websites belonging to the studied units, seen from the perspective of the criteria considered in accordance with the paper topic, consisted in assigning a grade to each criterion by itself (see Table 5), this meaning to the criterion regarded irrespective of any surrounding element. This allowed for the identification of the perceived impact level of the four criteria used on the target websites as a whole. 
Table 5: Grades assigned to the stand-alone criteria

\begin{tabular}{ccccc}
\hline & sntw_inv & need_conf & qck_access & web_style \\
\hline criterion grade & 9 & 10 & 10 & 8 \\
\hline
\end{tabular}

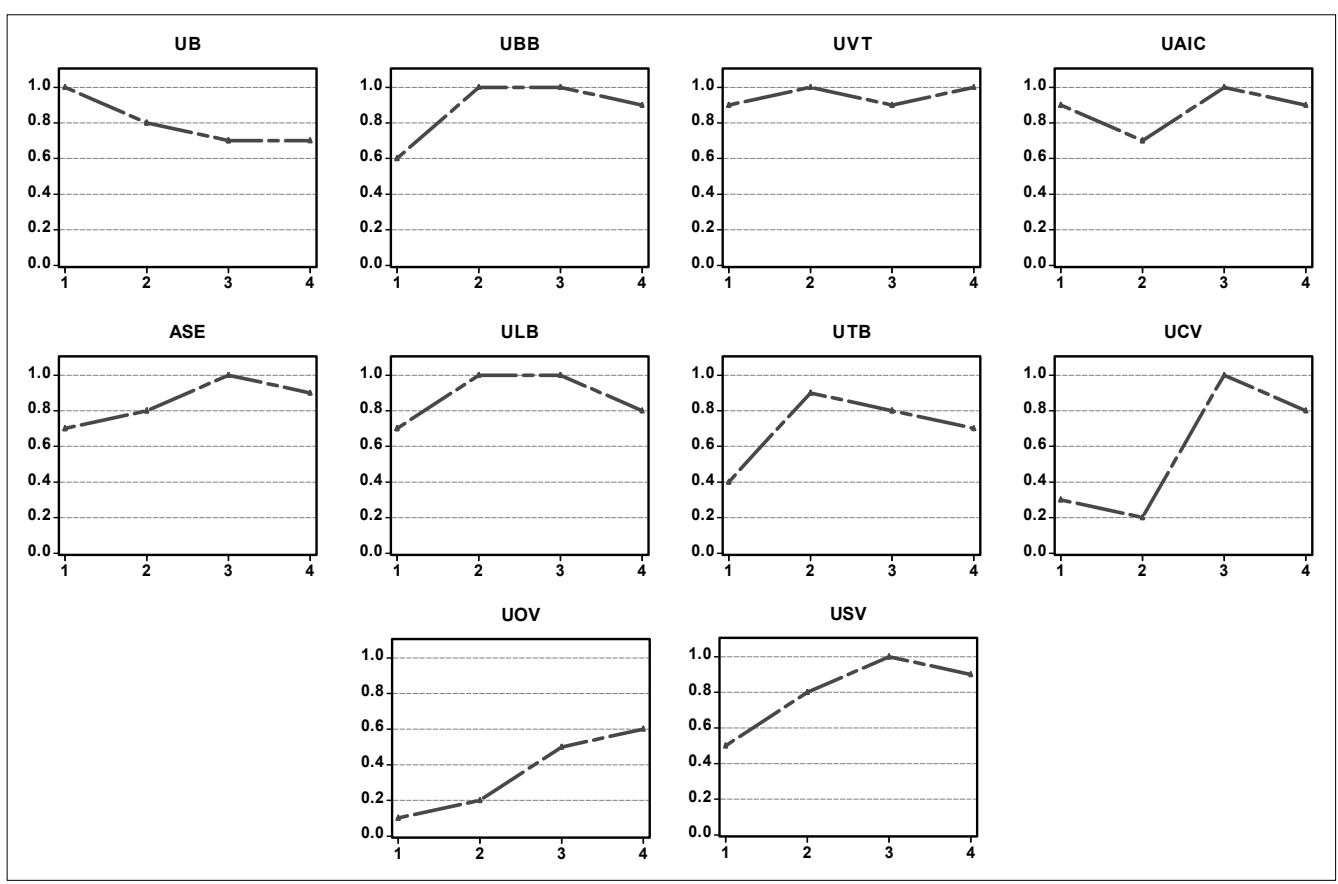

Figure 5: Grades assigned to the analyzed criteria for the studied websites

Figure 5, obtained by resorting to Eviews 5.0, reveals the structure of the grades assigned to each website for the four criteria considered. In these circumstances, it becomes really interesting to capture such graph in correlation with the importance of the selected stand-alone criteria, reflected by the grades presented in Table 5, the overall image suggesting some preliminary favorites to top positions (Babes-Bolyai University, West University of Timisoara and Lucian Blaga University of Sibiu, which received very good appreciations for the most important criteria: user need conformity criterion and user quick access to information criterion).

By gathering altogether, the grades rendered in Tables 1, 2, 3, 4 and 5, after having divided by 10 the data contained in the first four of them and after having normalized those comprised in the fifth one, for purposes strictly related to a proper implementation of the Fishbein-Rosenberg Model, we obtained the information exposed in Table 6, below: 
Table 6: Transformed values of the considered items and criteria

\begin{tabular}{cccccc}
\hline & & sntw_inv & need_conf & qck_acces & web_style \\
\hline CG & & 0.2432 & 0.2702 & 0.2702 & 0.2162 \\
\hline \multirow{4}{*}{} & ub & 1.0000 & 0.8000 & 0.7000 & 0.7000 \\
& ubb & 0.6000 & 1.0000 & 1.0000 & 0.9000 \\
& utv & 0.9000 & 1.0000 & 0.9000 & 1.0000 \\
& uaic & 0.9000 & 0.7000 & 1.0000 & 0.9000 \\
PG & ase & 0.7000 & 0.8000 & 1.0000 & 0.9000 \\
& ulb & 0.7000 & 1.0000 & 1.0000 & 0.8000 \\
& utb & 0.4000 & 0.9000 & 0.8000 & 0.7000 \\
& ucv & 0.3000 & 0.2000 & 1.0000 & 0.8000 \\
& uov & 0.1000 & 0.2000 & 0.5000 & 0.6000 \\
& usv & 0.5000 & 0.8000 & 1.0000 & 0.9000 \\
\hline
\end{tabular}

Last but not least, the results rendered in Table 7, arising from computation of the arithmetic mean of the 10 divided criteria-based partial grades of websites $\left(P G_{i j}\right)$ weighted with the normalized criterion relative importance-assigned value $\left(C G_{i}\right)$, according to the earlier mentioned formula, specific to the Fishbein-Rosenberg Model, gives us the possibility to classify the analyzed entities and to make some pertinent comments in this respect.

Table 7: Final results based on the Fishbein-Rosenberg Model

\begin{tabular}{cc}
\hline Website & FG \\
\hline ub & 0.8000 \\
\hline ubb & 0.8757 \\
\hline uvt & 0.9541 \\
\hline uaic & 0.8676 \\
ase & 0.8459 \\
ulb & 0.8730 \\
\hline utb & 0.7027 \\
\hline ucv & 0.5595 \\
uov & 0.3486 \\
\hline usv & 0.7973 \\
\hline
\end{tabular}

As we see, the higher ranked universities from the studied perspective, the ones better complying with the public governance exigencies in the matter, are those having registered high scores for at least three criteria out of the four criteria had in view. Given that, we understand that a proper communication is achievable via various channels that should be appropriately considered and continuously analyzed and improved in order to outperform.

\section{Recommendations}

The transition of the public institution from the bureaucratic model (limited communication under strict rules) to another model - New Public Management (the development of institutional communication to make the activity within the institution 
visible and ensure the legitimacy of its action, as well as the development of commercial communication to achieve beneficiaries satisfaction), then to Democratic Governance - represents a very difficult process that takes time and a change of mentality. This is the main explanation of the differences that occur in the degree of 'openness' of the university sites to the user. Some state universities transitioned faster than others from an institutional logic to one focused on services. Romania has a bureaucratic model in its collective unconscious, and the 'distance' between the public institution and the citizen is very high. Thus, it is difficult for the same citizen (a simple administered person during the communist period) to become a partner soon (with equal rights) of the public institution, of a university - in particular.

Therefore, starting from the results of our research, we recommend that the Romanian state universities develop a communication strategy, set on a medium term, which will guide the university communication towards covering the principles of the Democratic Governance Model. Prioritizing communication based on dialogue and interactivity should become a component of educational policy. State and private universities can develop, in the medium term, a communication strategy that incorporates: messages, stakeholders, channels, roles and responsibilities and strategic priorities. The University's website stakeholders must be both students and presumptive students, as well as co-workers, presumptive co-workers, alumni, research funders, research and education organizations, business, political organization, media, and the public.

The triangle made up of objectives, targets and means of communication (the three key elements of the communication plan) must be very well adapted to each of the stakeholders. Thus, for students we recommend the existence of the student portal as well as personal channels (the oral and written communication that students receive from teachers and others; direct communication remains the most efficient communication tool). The student portal should contain useful information: grades, fees, school status, student regulations, mobility information, student's Bachelor guide, student's Master guide, employment opportunities, information about the library, campus and student life. It is necessary to simplify the search and to save time. Prioritizing different channels for different stakeholders is a way to bring the institution closer to its receivers and to meet the demands of the Democratic Governance Model.

Also, the communication strategy, as an educational policy tool, must include the following priorities: to develop the university's internal communication, strengthen the communication work between the different parts of the University, develop the communication with students, focus on quality rather than quantity, establish continuous monitoring of the internal and external environments, choose the issues where the University wants to have an active role and build relations with important stakeholders.

The communication strategy must aim at better valorization of the university as a unique brand. In this respect, the University must look at the communication policy as a tool that contributes (along with other indicators) to is Brand Image and to every 
component of the whole (faculties, departments, centers of research, personal brands) to help this unique valorization process (institutional identity).

\section{Conclusions}

Given the results obtained, we can make a final classification (see Table 8) of the performance proved by the ten public universities, analyzed from the perspective of the observance by their websites of the Democratic Governance Principles.

Table 8: Final classification based on the Fishbein-Rosenberg Model-based results

\begin{tabular}{cl}
\hline Position & \multicolumn{1}{c}{$\begin{array}{c}\text { Websites of higher education public } \\
\text { institutions }\end{array}$} \\
\hline 1 & West University of Timisoara \\
2 & Babes-Bolyai University \\
3 & Lucian Blaga University of Sibiu \\
4 & Alexandru loan Cuza University of lasi \\
5 & Bucharest Academy of Economic Studies \\
6 & University of Bucharest \\
7 & Stefan cel Mare University of Suceava \\
8 & Transylvania University of Brasov \\
9 & University of Craiova \\
10 & Ovidius University of Constanta \\
\hline
\end{tabular}

The top reflects the extent to which the ten websites of the studied universities - by the way they are conceived - invite students to be part of the institution life (e-Participation), the larger or smaller distance created between the two. The compliance by the West University of Timisoara with the prerequisites specific to the new management model proves to be highly responsible: this website focuses on services, observes the user logic, is modern, attractive and invites to dialogue.

Also, we ascertain the fact that the websites of the five universities belonging to the Universitaria Consortium hold top positions in this hierarchy, being customized, responding to the requirements of users and correlating their action with the institutional one in order to achieve the target goals. At their turn, the other websites build a relationship of partnership with their students, too.

In the new vision, the users are not deemed to be any longer just objects of the website administration, passive receivers, but active participants, imprinting the university orientation and conditioning, directly or indirectly, its decisions.

The final classification reflects the level of synergy of the action of all actors of a university, a change of the organizational culture and a visible desire of such public institutions to comply with the student needs.

\section{References:}

1. Anderruthy, J.N., Du web 2.0 au web 3.0 les nouveaux services Internet, Saint Herblain: Edition ENI, 2009.

2. Bădău, H.M., Tehnici de comunicare în social media, Iaşi: Polirom, 2011. 
3. Bevir, M., Key Concepts in Governance, London: Sage, 2009.

4. Blond, M.V., Marcellin, O. and Zerbib, M., Lisibilité des sites web: des choix typographiques au design d'information, Paris: Eyrolles, 2009.

5. Chevallier, J., Le service public, Paris: PUF, 2012.

6. Cousin, C., Tout sur le web 2.0., Paris: Dunod, 2008.

7. Gany, D., Nouveaux médias, mode d'emploi, Liège: Edipro, 2009.

8. Lacroix, I. and St-Arnaud, P.O., 'La gouvernance: tenter une définition', 2012, in the Cahiers de recherche en politique appliquée, vol. IV, no. 3, pp. 19-37, [Online] available at http://ifgu.auf.org/media/document/Cahiers_de_recherche_en_politique_appliquée_ vol_IV_No_3.pdf, accessed on November 2, 2015.

9. Laroche, M., 'Four Methodological Problems in Multi-Attribute Models', in Hunt, K. (ed.), NA - Advances in Consumer Research, 1978, vol. 5, MI: Association for Consumer Research, pp. 175-179.

10. Lemaire, M. and Zémor, P., La communication publique en pratique, Paris: La documentation française, 2006.

11. Marga, A., 'University Governance', 2010, [Online] available at http://www.napocanews.ro/2010/02.rectorul-andrei-marga-despre-guvernanta-schimbare-culturala-ex celenta.html, accessed on November 5, 2015.

12. Mégard, D., La communication publique et territoriale, Paris: Dunod, 2012.

13. Monnoyer-Smith, L., 'La participation en ligne, révélateur d'une évolution des pratiques politiques', 2011, Participation (Démocratie et participation: un état des saviors), vol. 1, no. 1, pp. 156-185.

14. Nielsen, J. and Loranger, H., Site Web: de priorité à la simplicité, Paris: Pearson Education, 2009.

15. Osborne, S.P., The New Public Governance. Emerging Perspectives on the Theory and Practice of Public Sector, Routledge: London, 2010.

16. Pasquier, M., Communication publique, Bruxelles: Ed. de Boeck, 2011.

17. Ridgway, J., Relații cu media, Bucharest: Codecs, 2001. 